\title{
Successful Treatment of Experimental Escherichia coli Infections in Mice Using Phage: its General Superiority over Antibiotics
}

\author{
By H. WILLIAMS SMITH* AND M. B. HUGGINS \\ Houghton Poultry Research Station, Houghton, Huntingdon, \\ Cambridgeshire PE17 2DA, U.K.
}

(Received 28 April 1981; revised 7 July 1981)

\begin{abstract}
Anti-K 1 phages were more active in vitro and in vivo against an $018: \mathrm{K} 1: \mathrm{H}_{7} \mathrm{ColV}^{+}$ Escherichia coli strain, designated $\mathrm{MW}$, than were other phages. A single intramuscular dose of one anti-K1 phage was more effective than multiple intramuscular doses of tetracycline, ampicillin, chloramphenicol, or trimethoprim plus sulphafurazole in curing mice of a potentially lethal intramuscularly or intracerebrally induced infection of $\mathrm{MW}$; it was at least as effective as multiple intramuscular doses of streptomycin. When MW and the phage were inoculated into different gastrocnemius muscles of the same mice, a rapid reduction in numbers of MW organisms occurred in the MW-inoculated muscle and in other tissues; the numbers of phage particles in the MW-inoculated muscle increased rapidly and greatly. $\mathrm{MW}$ failed to proliferate in the brains of intracerebrally infected mice that had been inoculated intramuscularly with the phage at the same time; many more phage particles were found in the brains of these mice than in other sites. The few phage-resistant mutants of MW found in the phage-treated mice were $\mathrm{K}^{-}$; previous studies had shown such mutants to be of greatly reduced virulence.

The phage administered intramuscularly $3-5 \mathrm{~d}$ before challenge with a potentially lethal intramuscularly induced infection of $\mathrm{MW}$ was protective, the protective effect varying between phage propagated on different bacterial strains.
\end{abstract}

\section{INTRODUCTION}

The discovery in the 1920s of phages that attack pathogenic bacteria in vitro led to an intensive period of inquiry into their use for treating infectious disease. The earlier claims of success were not substantiated by carefully planned investigations and, hastened by the introduction of antibiotics, investigations into their use for this purpose were largely abandoned. Although phages have occasionally been reported as being effective in treating experimentally produced infections in laboratory animals, much of the success has either been against diseases that do not occur naturally in the test animal, such as Salmonella typhi infection in mice, or under conditions greatly weighted in favour of the phage rather than the infecting bacterium (Wilson \& Miles, 1975). The main reasons postulated for failure of phages to cure infections have been low degree of activity in vivo compared with that in vitro, and the rapid emergence of phage-resistant bacterial mutants. To investigate the validity of these reasons and to obtain more information on the microbial events that follow the introduction of a phage into animals suffering from bacterial infections, studies were carried out on mice that had first been infected with an Escherichia coli strain belonging to a serotype that not uncommonly causes generalized infections in man and animals, and then inoculated with phages. Because of the unexpectedly favourable results obtained in the treatment aspect of these studies, the investigation was extended to compare the efficacy of phages with that of antibiotics in treating both generalized and cerebral infections caused by this strain. 


\section{METHODS}

Bacterial strains. The O18ac: $\mathrm{K} 1: \mathrm{H}_{7} \mathrm{ColV}^{+} E$. coli strain, designated $\mathrm{MW}$, which was used in all infection experiments and for isolating and propagating phages, was prototrophic and non-haemolytic. It had been isolated from the brain of a human baby suffering from meningitis; its virulence, in which the $\mathrm{K} 1$ antigen was importantly involved, pathogenic characteristics and immunogenicity were the subject of a recent investigation (Smith \& Huggins, 1980). K1- mutants of this strain were identified by the method described by Smith \& Huggins (1980). The minimum inhibitory concentrations of antibiotics for it were determined by the method of Smith (1976). A prototrophic $E$. coli $\mathrm{K} 12$ strain into which the K 1 antigen had been transferred from an Hfr form of MW (Smith \& Huggins, 1980) was used for propagating phage R, a phage whose attack point was the K1 antigen (Gross et al., 1977).

Culture media and cultural conditions. Broth cultures consisted of organisms grown in $10 \mathrm{ml}$ nutrient broth, Oxoid no. 2 (CM67), in a shaking water bath (100 rev. $\left.\min ^{-1}\right)$. The nutrient agar employed was Difco tryptose agar (B64) and the MacConkey agar was from Oxoid (CM7). All cultures were incubated at $37^{\circ} \mathrm{C}$ for $24 \mathrm{~h}$.

Bacterial extracts. The cells in broth cultures were disrupted for $3 \mathrm{~min}$ by means of an ice-cooled MSE Mullard $60 \mathrm{~W}$ ultrasonic disintegrator at maximum output, employing a titanium probe of $19 \mathrm{~mm}$ diameter. The material was then centrifuged at $2500 \mathrm{~g}$ for $30 \mathrm{~min}$ and the supernate held at $58^{\circ} \mathrm{C}$ for $30 \mathrm{~min}$ and checked for bacterial sterility by inoculating $0.5 \mathrm{ml}$ into $10 \mathrm{ml}$ broth and incubating at $37^{\circ} \mathrm{C}$ for $24 \mathrm{~h}$.

Isolation and propagation of phages. These were isolated from raw sewage obtained from sewage works and pig markets. About $200 \mathrm{ml}$ sewage was diluted with $200 \mathrm{ml}$ broth and the mixture held at $58{ }^{\circ} \mathrm{C}$ for $30 \mathrm{~min}$. A $1 \mathrm{ml}$ portion of a broth culture of MW was added. After incubation for $1 \mathrm{~d}$, a $25 \mathrm{ml}$ portion was centrifuged at $2500 \mathrm{~g}$ for $30 \mathrm{~min}$, the supernate held at $58{ }^{\circ} \mathrm{C}$ for $30 \mathrm{~min}$ and one drop spot-inoculated on to the surface of a plate of nutrient agar that had previously been inoculated with a lawn of MW. Any area of phage lysis found on the plate after incubation was picked, and mixed with a small amount of a broth culture of MW on a plate of nutrient agar; the plate was incubated until discrete plaques were visible. A single plaque was picked and re-plated with MW and the process was repeated twice. Finally, a discrete plaque and some of the surrounding growth was picked into broth and incubated until lysis occurred. This lysate was held at $58{ }^{\circ} \mathrm{C}$ for $30 \mathrm{~min}$ and then added to $400 \mathrm{ml}$ of broth inoculated with $20 \mathrm{ml}$ of a broth culture of $\mathrm{MW}$ and incubated until lysis occurred. More broth culture was added and the process repeated. Finally, the phage preparation was held at $58^{\circ} \mathrm{C}$ for 30 min and then checked for phage potency and bacterial sterility. Phages were designated by letters; phage $R$ was designated $R(M W)$ when it had been propagated on $\mathrm{MW}$ and $\mathrm{R}\left(\mathrm{K} 12 . \mathrm{K} 1^{+}\right)$when it had been propagated on $\mathrm{K} 12 . \mathrm{K} 1^{+}$. Anti-K 1 phages were recognized by their ability to lyse $\mathrm{K}^{+}$but not $\mathrm{K}^{-}$forms of $\mathrm{MW}$ and $E$. coli $\mathrm{K} 12$.

Bacterial and phage counts. The numbers of bacteria and phage particles in cultures, body fluids and tissues were estimated by a modification of the method of Miles \& Misra (1938), using nutrient broth as diluent; tissue samples were first ground with sterile sand in a pestle and mortar or in a Griffith's tube. Bacterial counts were performed on MacConkey agar and phage counts on plates of nutrient agar whose entire surface had been spread with lawns of broth cultures of MW (approximately $10^{8}$ viable organisms per plate). Materials for phage assay, except spleen suspensions, were first held at $58{ }^{\circ} \mathrm{C}$ for $30 \mathrm{~min}$; spleen suspensions were not given this treatment because sometimes it reduced their phage titre.

Experimental animals and inoculation procedures. Unsexed White Swiss mice bred at this institute were used when they were $56 \mathrm{~d}$ old and weighed approximately $30 \mathrm{~g}$. Intramuscular inoculations of approximately 100 median lethal doses $\left(\mathrm{LD}_{50}\right)$ of $\mathrm{MW}\left(3 \times 10^{7}\right.$ viable organisms) were made into the left gastrocnemius muscle; intracerebral inocula comprised approximately $10 \times \mathbf{L D}_{50}$ (500 viable organisms). Unless otherwise stated, phage-treated mice were given $3 \times 10^{8}$ viable phage particles. Antibiotics, each dose at $25 \mathrm{mg}\left(\mathrm{kg}\right.$ body wt) ${ }^{-1}$, were given to mice as a single dose or as repeated doses at $12 \mathrm{~h}$ intervals. Phage and antibiotic inoculations were made into the right gastrocnemius muscle.

\section{RES ULTS}

\section{In vitro activity of phages against $M W$}

Of 15 phages that were isolated from specimens of sewage, 9 were identified as anti-K 1 . The approximate diameter of plaques of the anti-K1 phages was $1.5 \mathrm{~mm}$ and that of the other phages was $0.5 \mathrm{~mm}$. The anti-K1 phages were much more virulent than the other phages; fewer than 10 viable particles of the anti-K1 phages were required to lyse broth cultures seeded with $3 \times 10^{8}$ viable organisms of $\mathrm{MW}$, whereas $10^{6}-10^{9}$ viable particles of the other phages were required. MW cultures contained more mutants resistant to the anti-K 1 phages than to the other phages; for example, 50-120 resistant colonies grew within the zone of lysis produced by one drop of undiluted preparations of the anti-K 1 phages spotted on a lawn of MW, whereas the number that grew in the case of the other phages was $0-5$. The mutants 


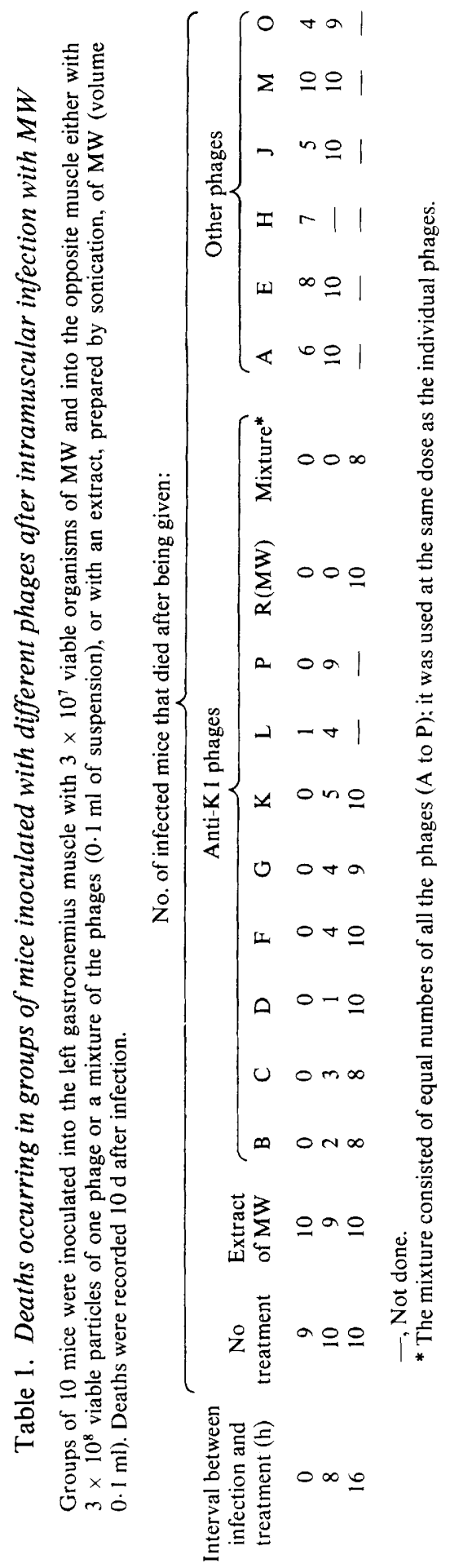


Table 2. Deaths occurring in groups of mice given different doses of phage $R\left(K 12 . K 1^{+}\right)$ intramuscularly or intravenously at the same time as they were infected intramuscularly with $M W$

Groups of 10 mice were inoculated into the left gastrocnemius muscle with $3 \times 10^{7}$ viable organisms of MW and at the same time received varying doses of phage either in the opposite muscle or intravenously. Deaths were recorded $10 \mathrm{~d}$ after infection.

$\begin{array}{ccc}\begin{array}{c}\text { Dose of } \mathrm{R}\left(\mathrm{K} 12 . \mathrm{K}^{+}\right)^{*} \\ \text { (no. of viable particles) }\end{array} & 0 & \text { Intravenously } \\ 3 \times 10^{7} & 0 & - \\ 3 \times 10^{6} & 0 & 0 \\ 3 \times 10^{5} & 0 & 0 \\ 3 \times 10^{4} & 6 & 3 \\ 3 \times 10^{3} & 10 & 6 \\ 3 \times 10^{2} & 10 & 9 \\ 30 & - & 10 \\ 3 & 10 & \\ 0 & \end{array}$

resistant to all the phages were non-lysogenic; those resistant to the anti-K1 phages were $\mathrm{K}^{-}$.

\section{Effect of different phages on the numbers of mice dying when infected intramuscularly with $M W$}

A great difference in mortality was noted between groups of mice that were inoculated with one or other of the 15 phages after they had been infected intramuscularly with MW (Table 1). The lowest numbers of deaths were in the groups inoculated with the anti-K1 phages; these included phage $\mathrm{R}(\mathrm{MW})$ which had been isolated from the blood of a mouse $24 \mathrm{~h}$ after it had been inoculated with MW and $8 \mathrm{~h}$ after it had been inoculated with a mixture of all the other phages. Numbers of deaths were usually lower in the groups of mice in which phages were given at the same time as MW than in the groups in which they were given $8 \mathrm{~h}$ later. Phages given $16 \mathrm{~h}$ after MW had little effect on the course of the disease; by this time, however, all the untreated mice appeared distinctly unwell and by $24 \mathrm{~h}$ more than half of them had died. The course of the disease in MW-infected mice given an extract of MW prepared by ultrasonication was similar to that in the untreated ones; this extract was included as a control in this and subsequent experiments because it would be expected to contain much the same bacterial components as the phage preparations.

Inoculation of groups of MW-infected mice intramuscularly or intravenously with 10 -fold falling numbers of phage $\mathrm{R}\left(\mathrm{K} 12 . \mathrm{K}^{+}\right)$(i.e. phage $\mathrm{R}$ that had been propagated on $E$. coli $\mathrm{K} 12 . \mathrm{K}^{+}$) revealed that low numbers, especially when given intravenously, were sufficient to prevent the mice from dying (Table 2). Similar results were obtained when this experiment was repeated.

\section{Effect of phage $\mathrm{R}\left(\mathrm{K} 12 . \mathrm{KI}^{+}\right)$and antibiotics on the numbers of mice dying when infected intramuscularly or intracerebrally with $M W$}

The mortality in groups of mice infected intramuscularly with MW and given one dose of phage $R\left(K 12 . K 1^{+}\right) 8 \mathrm{~h}$ later was significantly lower than that in groups of $\mathrm{MW}$-infected mice that were given instead one or eight doses of tetracycline, ampicillin or chloramphenicol, or of a mixture of equal parts of trimethoprim and sulphafurazole, or one dose of streptomycin; the numbers dying in a group given eight doses of streptomycin were about the same as in the $\mathrm{R}\left(\mathrm{K} 12 . \mathrm{K}^{+}\right)$-treated mice (Table 3 ). All the deaths occurred within $4 \mathrm{~d}$ of infection. The 
Table 3. Deaths occurring in groups of mice infected intramuscularly with $M W$ and then treated intramuscularly with either phage $R\left(K 12 . K 1^{+}\right)$or antibiotics

Groups of 30 mice were inoculated into the left gastrocnemius muscle with $3 \times 10^{7}$ viable organisms of MW. Phage $\left(3 \times 10^{8}\right.$ viable particles), bacterial extract or antibiotic was inoculated into the opposite muscle, the first dose of each given $8 \mathrm{~h}$ after $\mathrm{MW}$ infection, and then (in the case of the antibiotics given in multiple dosage) every $12 \mathrm{~h}$ for $4 \mathrm{~d}$. Each dose of the antibiotics, including the two components of the trimethoprim/sulphafurazole mixture, was $25 \mathrm{mg}(\mathrm{kg} \text { body wt })^{-1}$. Deaths were recorded $10 \mathrm{~d}$ after infection.

$\begin{array}{ll}\text { No. of } & \begin{array}{l}\text { No. of } \\ \text { doses }\end{array} \\ \text { deaths }\end{array}$

\begin{tabular}{|c|c|c|}
\hline Extract of $E$. coli $\mathrm{K} 12 . \mathrm{K}^{+}$ & 1 & 28 \\
\hline Phage R(K12.K1+) & 1 & 2 \\
\hline Streptomycin & 1 & 29 \\
\hline Streptomycin & 8 & 3 \\
\hline Tetracycline & 1 & 23 \\
\hline Tetracycline & 8 & 13 \\
\hline Ampicillin & 1 & 30 \\
\hline Ampicillin & 8 & 26 \\
\hline Chloramphenicol & 1 & 30 \\
\hline Chloramphenicol & 8 & 29 \\
\hline Trimethoprim and sulphafurazole & 1 & 28 \\
\hline Trimethoprim and sulphafurazole & 8 & 26 \\
\hline
\end{tabular}

Table 4. Deaths occurring in groups of mice infected intracerebrally with $M W$ and then treated intramuscularly with either phage $R\left(K 12 . K 1^{+}\right)$or antibiotics

Groups of 32 mice were used. Treatment commenced $16 \mathrm{~h}$ after infection with approximately 500 viable organisms of MW in $0.02 \mathrm{ml}$ of physiological saline. Only one dose of bacterial extract and one dose $\left(3 \times 10^{8}\right.$ viable particles $)$ of phage $\mathrm{R}\left(\mathrm{K} 12 . \mathrm{K}^{+}\right)$were given. The antibiotics were given, in doses of $25 \mathrm{mg}(\mathrm{kg} \text { body } \mathrm{wt})^{-1}$, every $12 \mathrm{~h}$ for $6 \mathrm{~d}$.

No. of
Teaths

$\begin{array}{ll}\text { Extract of } E . \text { coli } \mathrm{K} 12 . \mathrm{K}^{+} & 31 \\ \text { Phage } \mathrm{R}\left(\mathrm{K} 12 . \mathrm{K}^{+}\right) & 13 \\ \text { Streptomycin } & 18 \\ \text { Tetracycline } & 26 \\ \text { Ampicillin } & 28 \\ \text { Chloramphenicol } & 28 \\ \text { Trimethoprim and sulphafurazole } & 26\end{array}$

minimum inhibitory concentrations of streptomycin, tetracycline, ampicillin, chloramphenicol, trimethoprim and sulphafurazole for MW were $2 \cdot 0,0 \cdot 8,1 \cdot 5,3 \cdot 0,0.8$ and $50 \mu \mathrm{g} \mathrm{m} l^{-1}$ respectively. Eleven days after the commencement of the experiment, all 28 surviving mice in the $\mathrm{R}\left(\mathrm{K} 12 . \mathrm{K} 1^{+}\right)$-treated group appeared normal except for 13 that had a macroscopic lesion at the MW-inoculation site; a similar lesion was present in 20 of the 27 surviving mice that had been given eight doses of streptomycin.

The mortality in a group of mice infected intracerebrally with $\mathrm{MW}$ and then given phage $\mathrm{R}\left(\mathrm{K} 12 . \mathrm{K}^{+}\right)$intramuscularly $16 \mathrm{~h}$ later was significantly lower than that in groups of mice that were given instead 12 doses of tetracycline, ampicillin, chloramphenicol, or a mixture of trimethoprim and sulphafurazole but not of streptomycin (Table 4). Most of the deaths occurred within $4 \mathrm{~d}$ of infection. Many of the mice in this experiment exhibited pronounced signs of dysfunction of the central nervous system for several days before they died. Large numbers of MW organisms were isolated from the brain of most of the mice that died, but none or only very low numbers were found in other organs or in the blood. All the isolates of MW from the brain were antibiotic sensitive. When the experiment was terminated at $10 \mathrm{~d}, 9$ of the 14 streptomycin-treated survivors and only 6 of the 19 phage-treated survivors were exhibiting signs of residual brain damage; otherwise all 33 mice appeared healthy. 
Table 5. Counts on the tissues of mice killed at different times after intramuscular inoculation with $3 \times 10^{7}$ viable organisms of $M W$

Three mice were killed at each of the stated times and the numbers of MW organisms in their tissues were counted as described in Methods; the median of each set of three counts is shown.

$\begin{gathered}\text { Time after } \\ \text { inoculation } \\ \text { (h) }\end{gathered}$
$0(5 \mathrm{~min})$
1
3
5
8
12
16
20
24
25
28

\begin{tabular}{|c|c|c|c|c|c|}
\hline $\begin{array}{l}\text { Inoculated } \\
\text { muscle }\end{array}$ & $\begin{array}{l}\text { Uninoculated } \\
\text { musclet }\end{array}$ & Blood & Spleen & Liver & Brain \\
\hline 7.6 & $<2 \cdot 0$ & $2 \cdot 9$ & $2 \cdot 6$ & $2 \cdot 5$ & $<2 \cdot 0$ \\
\hline 7.7 & $3 \cdot 2$ & $4 \cdot 6$ & $5 \cdot 3$ & $4 \cdot 2$ & 2.9 \\
\hline $8 \cdot 5$ & $2 \cdot 3$ & 3.6 & $4 \cdot 3$ & $3 \cdot 3$ & $2 \cdot 0$ \\
\hline $9 \cdot 3$ & $2 \cdot 6$ & $3 \cdot 0$ & 3.7 & 3.7 & $2 \cdot 0$ \\
\hline 9.5 & 3.7 & 5.5 & $4 \cdot 2$ & $4 \cdot 0$ & $3 \cdot 3$ \\
\hline 9.5 & $4 \cdot 0$ & $4 \cdot 0$ & 4.4 & 4.4 & 2.7 \\
\hline $10 \cdot 0$ & $3 \cdot 0$ & 4.4 & 5.5 & $4 \cdot 7$ & $3 \cdot 0$ \\
\hline $10 \cdot 5$ & $4 \cdot 5$ & 6.6 & $7 \cdot 6$ & 7.0 & $4 \cdot 4$ \\
\hline $10 \cdot 5$ & 5.4 & $5 \cdot 5$ & 7.4 & $6 \cdot 4$ & $4 \cdot 0$ \\
\hline 10.0 & 6.6 & $7 \cdot 0$ & 9.0 & $8 \cdot 5$ & $4 \cdot 7$ \\
\hline $10 \cdot 5$ & $5 \cdot 5$ & $5 \cdot 7$ & 7.0 & $7 \cdot 5$ & 4.0 \\
\hline
\end{tabular}

* A number preceded by < is the lower limit of detection.

$\dagger$ Gastrocnemius muscle from uninoculated leg.

Table 6. Counts on the tissues of mice killed at different times after intramuscular inoculation with $3 \times 10^{8}$ viable particles of phage $R\left(K 12 . K 1^{+}\right)$

Three mice were killed at each of the stated times and the numbers of phage particles in their tissues were counted as described in Methods; the median of each set of three counts is shown.

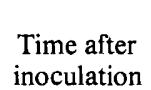

(h)

$0(5 \mathrm{~min})$
1
3
5
8
12
16
20
24
32
48
72
336
672

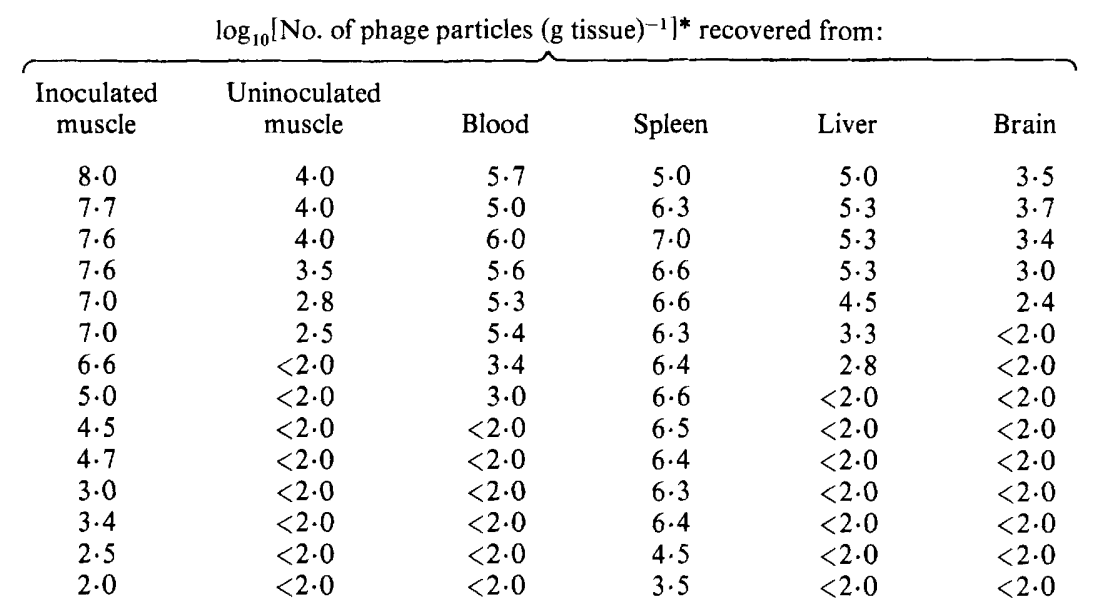

\footnotetext{
* See Table 5 .
}

Fate of $\mathrm{MW}$ and of phages $\mathrm{R}\left(\mathrm{KI} 2 \mathrm{K1^{+ }}\right)$ and $\mathrm{O}$ in the tissues of mice that had been inoculated intramuscularly or intracerebrally with them

Counts were made on the tissues of mice killed at different times after $3 \times 10^{7}$ viable organisms of MW had been inoculated into one of their gastrocnemius muscles. These revealed that $\mathrm{MW}$ multiplied rapidly in the inoculation site and was present there in very high numbers when the animals were near to death - usually 20-28 h after inoculation (Table 5). Low numbers were present in the uninoculated muscle, blood, spleen, liver and brain of the mice examined $5 \mathrm{~min}$ after inoculation. The bacteria were found in increasingly high numbers in the mice killed subsequently; the more severely ill the mouse, the greater were the numbers in its tissues. The numbers in the brain were always comparatively low. 
Table 7. Counts on the tissues of mice killed at different times after $3 \times 10^{7}$ viable organisms of $M W$ had been inoculated into one of their gastrocnemius muscles at the same time as

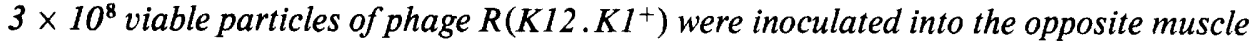

Three mice were killed at each of the stated times and the numbers of MW organisms and $\mathrm{R}$ phage particles in their tissues were counted; the median of each set of three counts is shown.

\begin{tabular}{|c|c|c|c|c|c|c|}
\hline \multirow{3}{*}{$\begin{array}{c}\text { Time after } \\
\text { inoculation of } \mathrm{MW} \\
\text { (h) }\end{array}$} & \multicolumn{6}{|c|}{$\begin{array}{l}\log _{10}\left[\text { No. of organisms or phage particles }(\mathrm{g} \text { tissue })^{-1}\right]^{*} \\
\text { recovered from: }\end{array}$} \\
\hline & \multicolumn{2}{|c|}{$\begin{array}{c}\text { MW-inoculated } \\
\text { muscle }\end{array}$} & \multicolumn{2}{|c|}{ Blood } & \multicolumn{2}{|c|}{ Spleen } \\
\hline & MW & $\mathbf{R}$ & MW & R & MW & R \\
\hline $0(5 \mathrm{~min})$ & 7.0 & $4 \cdot 4$ & $4 \cdot 6$ & 5.7 & 4.4 & $4 \cdot 6$ \\
\hline 1 & $5 \cdot 4$ & $8 \cdot 4$ & $2 \cdot 5$ & $6 \cdot 2$ & $3 \cdot 3$ & $6 \cdot 0$ \\
\hline 3 & $5 \cdot 7$ & 8.6 & $<2.0$ & $6 \cdot 6$ & 3.0 & 6.6 \\
\hline 5 & $5 \cdot 0$ & $8 \cdot 4$ & $<2 \cdot 0$ & $5 \cdot 5$ & $<2.0$ & $7 \cdot 0$ \\
\hline 8 & $5 \cdot 0$ & 7.8 & $<2.0$ & $5 \cdot 7$ & $<2.0$ & $7 \cdot 5$ \\
\hline 16 & $5 \cdot 3$ & $7 \cdot 6$ & $<2 \cdot 0$ & $5 \cdot 3$ & $<2.0$ & $7 \cdot 0$ \\
\hline 20 & $5 \cdot 0$ & 7.0 & $<2.0$ & $5 \cdot 0$ & $<2.0$ & 7.0 \\
\hline 24 & $5 \cdot 0$ & $6 \cdot 3$ & $<2.0$ & 4.7 & $<2.0$ & $6 \cdot 7$ \\
\hline 32 & $4 \cdot 5$ & $5 \cdot 8$ & $<2.0$ & $<2.0$ & $<2 \cdot 0$ & $7 \cdot 0$ \\
\hline 48 & $4 \cdot 5$ & 3.4 & $<2.0$ & $<2.0$ & $<2.0$ & $7 \cdot 2$ \\
\hline 72 & $3 \cdot 5$ & 2.5 & $<2.0$ & $<2.0$ & $<2.0$ & $7 \cdot 0$ \\
\hline 120 & $2 \cdot 0$ & $2 \cdot 0$ & $<2.0$ & $<2.0$ & $<2 \cdot 0$ & 6.7 \\
\hline
\end{tabular}

Five minutes after being inoculated into a gastrocnemius muscle in a dose of $3 \times 10^{8}$ viable particles, phage $\mathrm{R}\left(\mathrm{K} 12 . \mathrm{K} 1^{+}\right)$was found in fairly high numbers in the blood, spleen, liver, brain and uninoculated gastrocnemius muscle (Table 6). They persisted in the blood, liver, uninoculated muscle and brain for a shorter time than they did in the inoculated muscle and, especially, the spleen. Similar results were obtained in mice inoculated with the less virulent non-anti-K 1 phage $O$ (Table 1) except that this phage persisted for slightly longer in some of the tissues.

In mice inoculated simultaneously with $\mathrm{MW}$ into one gastrocnemius muscle and phage $\mathrm{R}\left(\mathrm{K} 12 . \mathrm{K}^{+}\right)$into the other, the number of MW organisms in the muscle into which they had been inoculated was low in all the mice killed $1 \mathrm{~h}$ or more later, much lower than in the muscle of those killed at $5 \mathrm{~min}$ (Table 7). None of the mice used in this experiment ever appeared unwell. Examination of 10 isolates of MW from the inoculated muscle of each of 31 mice killed $1-48 \mathrm{~h}$ after inoculation revealed that only 3 of the 310 isolates, one from each of three mice, were phage $\mathrm{R}$ resistant; these three isolates were all $\mathrm{K}^{-}$. MW organisms were not isolated from the blood or spleen of any of the mice killed more than $3 \mathrm{~h}$ after inoculation. In the MW-inoculated muscles of the mice examined at 1-20 h, the numbers of $R\left(K 12 . \mathrm{K}^{+}\right)$ particles usually exceeded the numbers of MW organisms by 100-1000 times; phage particles were about 10000-100000 times more numerous than they were in the corresponding site of mice given phage $\mathrm{R}\left(\mathrm{K} 12 . \mathrm{K} 1^{+}\right)$alone (Table 6). In this period, too, the numbers of $\mathrm{R}\left(\mathrm{K} 12 . \mathrm{K}^{+}\right)$in the blood and spleen were often about 3-10 times higher than they were in the mice given $\mathrm{R}\left(\mathrm{K} 12 . \mathrm{K}^{+}\right)$alone.

In MW-infected mice inoculated with phage $8 \mathrm{~h}$ later, the numbers of $\mathrm{MW}$ in the $\mathrm{MW}$-inoculated muscle of mice examined $2 \mathrm{~h}$ or more after phage administration were usually 10 or more times lower than they were in the mice examined before that time (Table 8). Ten isolates of $\mathrm{MW}$ from the inoculated muscle of each of the 36 mice that were examined between 9 and $168 \mathrm{~h}$ after infection were tested for resistance to phage $\mathrm{R}\left(\mathrm{K} 12 . \mathrm{K} 1^{+}\right)$. Of the 360 isolates, 15 representing 10 mice, were resistant and all of these were $\mathrm{K}^{-}{ }^{-}$. None of the mice in this experiment died and MW was not isolated from the blood, or spleen, of any of 
Table 8. Counts on the tissues of mice killed at different times after $3 \times 10^{7}$ viable organisms of $M W$ had been inoculated into one of their gastrocnemius muscles followed 8 h later by $3 \times 10^{8}$ viable particles of phage $R\left(K 12 . K 1^{+}\right)$into the opposite muscle

Three mice were killed at each of the stated times and the numbers of MW organisms and R phage particles in their tissues were counted; the median of each set of three counts is shown.

\begin{tabular}{|c|c|c|c|c|c|c|}
\hline \multirow{3}{*}{$\begin{array}{l}\text { Time after } \\
\text { inoculation of } \mathrm{MW} \\
\text { (h) }\end{array}$} & \multicolumn{6}{|c|}{$\begin{array}{l}\log _{10}\left[\text { No. of organisms or phage particles }(\mathrm{g} \text { tissue })^{-1}\right]^{*} \\
\text { recovered from: }\end{array}$} \\
\hline & \multicolumn{2}{|c|}{$\begin{array}{l}\text { MW-inoculated } \\
\text { muscle }\end{array}$} & \multicolumn{2}{|c|}{ Blood } & \multicolumn{2}{|c|}{ Spleen } \\
\hline & MW & $\mathbf{R}$ & $\mathrm{MW}$ & $\mathbf{R}$ & MW & $\mathbf{R}$ \\
\hline 8 & 9.6 & - & $4 \cdot 3$ & - & $4 \cdot 0$ & - \\
\hline 9 & 9.6 & 7.0 & 3.4 & 6.2 & 3.6 & $6 \cdot 0$ \\
\hline 11 & 7.6 & 9.4 & $<3.0$ & $6 \cdot 5$ & $2 \cdot 4$ & $6 \cdot 5$ \\
\hline 12 & 8.8 & $10 \cdot 5$ & $<3.0$ & $7 \cdot 2$ & 3.0 & $7 \cdot 2$ \\
\hline 16 & 8.0 & 9.4 & $<3.0$ & 7.7 & $<3 \cdot 0$ & $7 \cdot 4$ \\
\hline 20 & 8.5 & 9.7 & $<3.0$ & 8.7 & $<3.0$ & $8 \cdot 2$ \\
\hline 24 & 8.4 & 9.4 & $<3.0$ & $9 \cdot 0$ & $<3.0$ & $8 \cdot 0$ \\
\hline 32 & 8.0 & $8 \cdot 3$ & $<3.0$ & 7.5 & $<3.0$ & 8.0 \\
\hline 40 & 8.5 & $8 \cdot 6$ & $<2.0$ & 5.4 & $<3.0$ & $8 \cdot 2$ \\
\hline 68 & 8.6 & $8 \cdot 5$ & $<2 \cdot 0$ & $4 \cdot 5$ & $<3.0$ & 8.0 \\
\hline 92 & $7 \cdot 4$ & 7.0 & $<2.0$ & $3 \cdot 2$ & $<3.0$ & $7 \cdot 5$ \\
\hline 384 & 7.7 & $7 \cdot 5$ & $<2.0$ & $<2.0$ & $<2.0$ & $6 \cdot 8$ \\
\hline 624 & 3.4 & $<2.0$ & $<2 \cdot 0$ & $<2 \cdot 0$ & $<2.0$ & $5 \cdot 3$ \\
\hline
\end{tabular}

those examined more than $1 \mathrm{~h}$, or 4 or $5 \mathrm{~h}$ respectively, after phage administration. Much higher numbers of $\mathrm{R}\left(\mathrm{K} 12 . \mathrm{K}^{+}\right)$were found in $\mathrm{MW}$-inoculated muscle, blood and spleen of these mice than were found in the mice that had been given $\mathrm{MW}$ and $\mathrm{R}\left(\mathrm{K} 12 . \mathrm{K}^{+}\right)$simultaneously (Table 7) or $\mathrm{R}\left(\mathrm{K} 12 . \mathrm{K}^{+}\right.$) alone (Table 6); phage particles also persisted longer in the blood than they did in the previous experiments.

The experiments with MW and phage $\mathrm{R}\left(\mathrm{K} 12 . \mathrm{K} 1^{+}\right)$(Tables 7 and 8 ) were repeated using phage $\mathrm{O}$ instead of $\mathrm{R}\left(\mathrm{K} 12 . \mathrm{K} 1^{+}\right)$. There was little or no reduction in the numbers of $\mathrm{MW}$ organisms in the MW-inoculated muscle of the mice that had been inoculated simultaneously with $\mathrm{MW}$ and $\mathrm{O}$. In animals examined at $32-40 \mathrm{~h}$, the time when about half of the remaining mice died in this experiment, the numbers of MW had increased greatly; MW organisms were also present in the blood and spleen of these mice. In the experiment in which phage $\mathrm{O}$ was given $8 \mathrm{~h}$ after MW, all the mice that were not killed for examination died within $32 \mathrm{~h}$; MW organisms were found in very high numbers in the $\mathrm{MW}$-inoculated muscle of all the killed mice and they were also found in the blood and spleen. No MW organisms resistant to phage $O$ were isolated from any mice. Only low numbers of phage $\mathrm{O}$ were found in the $\mathrm{MW}$-inoculated muscle of the mice killed in the early stages of both experiments. Higher numbers were found in the mice killed subsequently, but even then, in the mice treated $8 \mathrm{~h}$ after infection, they were never much greater than the numbers of MW organisms also present in the inoculated muscle. Phage particles were also found in the blood and spleen of the mice used in both experiments, but in numbers little higher than those in mice given phage $\mathrm{O}$ alone.

Increasingly high numbers of organisms were found in the brains of mice examined $3 \mathrm{~h}$ or more after they had been inoculated intracerebrally with 500 viable organisms of $\mathrm{MW}$; very high numbers were present in the brains of those examined after $20 \mathrm{~h}$ or more (Table 9). Only low numbers were found in the blood and spleen of these mice. Most of the mice in this experiment were very unwell and severely ataxic by $28 \mathrm{~h}$ after inoculation; about $50 \%$ of them had died by $72 \mathrm{~h}$ and $75 \%$ of them by $96 \mathrm{~h}$. When mice were given $3 \times 10^{8}$ viable particles of phage $\mathrm{R}\left(\mathrm{K} 12 . \mathrm{K}^{+}\right)$into a gastrocnemius muscle at the same time as they were 
Table 9. Counts on the tissues of mice killed at different times after intracerebral inoculation with 500 viable organisms of $M W$

Three mice were killed at each of the stated times and the numbers of MW organisms in their tissues were counted; the median of each set of three counts is shown.

\begin{tabular}{|c|c|c|c|}
\hline \multirow{2}{*}{$\begin{array}{c}\text { Time after } \\
\text { inoculation of MW } \\
\text { (h) }\end{array}$} & \multicolumn{3}{|c|}{$\begin{array}{c}\left.\log _{10}[\text { No. of organisms (g tissue })^{-1}\right]^{*} \\
\text { recovered from: }\end{array}$} \\
\hline & Brain & Blood & Spleen \\
\hline $0(5 \mathrm{~min})$ & 2.5 & $<2.0$ & $<2.0$ \\
\hline 1 & $2 \cdot 0$ & $<2.0$ & 2.0 \\
\hline 3 & $3 \cdot 2$ & $<2.0$ & $<2.0$ \\
\hline 5 & $4 \cdot 0$ & $<2 \cdot 0$ & $<2 \cdot 0$ \\
\hline 8 & $4 \cdot 5$ & $2 \cdot 0$ & $<2 \cdot 0$ \\
\hline 12 & $6 \cdot 0$ & $2 \cdot 6$ & $2 \cdot 0$ \\
\hline 16 & $7 \cdot 7$ & 3.7 & $3 \cdot 3$ \\
\hline 20 & $8 \cdot 7$ & $4 \cdot 0$ & $2 \cdot 5$ \\
\hline 24 & 9.7 & 4.0 & $2 \cdot 8$ \\
\hline 32 & 9.3 & 3.6 & $3 \cdot 3$ \\
\hline 40 & 9.7 & $3 \cdot 8$ & $3 \cdot 5$ \\
\hline 48 & $9 \cdot 0$ & $3 \cdot 3$ & $2 \cdot 3$ \\
\hline 96 & 9.5 & $5 \cdot 5$ & $2 \cdot 7$ \\
\hline 120 & $8 \cdot 3$ & $<2.0$ & $<2.0$ \\
\hline
\end{tabular}

* See Table 5.

Table 10. Counts on the tissues of mice killed at different times after 500 viable organisms of $M W$ had been inoculated into their cerebrum at the same time as $3 \times 10^{8}$ viable particles of phage $R\left(K 12 . \mathrm{KI}^{+}\right)$were inoculated into one of their gastrocnemius muscles

Three mice were killed at each of the stated times and the numbers of MW organisms and R phage particles in their tissues were counted; the median of each set of three counts is shown.

\begin{tabular}{|c|c|c|c|c|c|c|}
\hline \multirow{3}{*}{$\begin{array}{l}\text { Time after } \\
\text { inoculation of } \mathrm{MW} \\
\text { (h) }\end{array}$} & \multicolumn{6}{|c|}{$\begin{array}{l}\log _{10}\left[\text { No. of organisms or phage particles }(\mathrm{g} \text { tissue })^{-1}\right]^{*} \\
\text { recovered from: }\end{array}$} \\
\hline & \multicolumn{2}{|c|}{ Brain } & \multicolumn{2}{|c|}{ Blood } & \multicolumn{2}{|c|}{ Spleen } \\
\hline & MW & $\mathbf{R}$ & MW & $\mathbf{R}$ & MW & $\mathbf{R}$ \\
\hline $0(5 \mathrm{~min})$ & $2 \cdot 3$ & $2 \cdot 0$ & $<2.0$ & $5 \cdot 5$ & $<2.0$ & $4 \cdot 7$ \\
\hline 1 & $<2.0$ & $<2.0$ & $<2.0$ & 5.7 & $<2.0$ & $6 \cdot 3$ \\
\hline 3 & $4 \cdot 2$ & $<2.0$ & $<2.0$ & $4 \cdot 3$ & $<2.0$ & $6 \cdot 2$ \\
\hline 5 & $4 \cdot 2$ & $<2.0$ & $<2.0$ & $5 \cdot 0$ & $<2.0$ & $5 \cdot 8$ \\
\hline 8 & $5 \cdot 3$ & 3.5 & $<2.0$ & 4.7 & $<2.0$ & $6 \cdot 2$ \\
\hline 12 & $5 \cdot 0$ & $6 \cdot 5$ & $<2.0$ & $5 \cdot 0$ & $<2.0$ & 6.4 \\
\hline 16 & 5.0 & 8.2 & $<2.0$ & $5 \cdot 0$ & $<2.0$ & 6.7 \\
\hline 20 & $5 \cdot 3$ & $7 \cdot 8$ & $<2.0$ & $4 \cdot 5$ & $<2.0$ & $6 \cdot 2$ \\
\hline 24 & $4 \cdot 6$ & 7.8 & $<2.0$ & $3 \cdot 2$ & $<2 \cdot 0$ & $6 \cdot 5$ \\
\hline 32 & $4 \cdot 3$ & $6 \cdot 5$ & $<2.0$ & $2 \cdot 0$ & $<2.0$ & $6 \cdot 5$ \\
\hline 40 & $4 \cdot 2$ & $5 \cdot 7$ & $<2.0$ & $2 \cdot 0$ & $<2.0$ & $6 \cdot 0$ \\
\hline 48 & $4 \cdot 7$ & 7.0 & $<2.0$ & $<2.0$ & $<2.0$ & 6.0 \\
\hline 96 & 4.4 & $4 \cdot 5$ & $<2.0$ & $<2 \cdot 0$ & $<2.0$ & $5 \cdot 5$ \\
\hline 120 & $3 \cdot 1$ & 4.7 & $<2.0$ & $<2.0$ & $<2.0$ & $5 \cdot 7$ \\
\hline 168 & 2.0 & $2 \cdot 0$ & $<2.0$ & $<2.0$ & $<2.0$ & 6.0 \\
\hline 240 & $<2.0$ & $<2.0$ & $<2.0$ & $<2.0$ & $<2.0$ & $4 \cdot 0$ \\
\hline
\end{tabular}

* See Table 5.

infected intracerebrally with MW, none of them died, and only low numbers of MW were found in their brains and none in their blood and spleens (Table 10). Ten isolates of MW from the brain of each of the 36 mice examined between 16 and $168 \mathrm{~h}$ after infection were examined for sensitivity to phage $\mathrm{R}\left(\mathrm{K} 12 . \mathrm{K}^{+}\right)$. Of these 360 isolates only 6 , representing five 
Table 11. Deaths occurring in groups of mice given different treatments intramuscularly at different times before challenge with $M W$

Groups of 20 mice were used. The phage dose was $3 \times 10^{8}$ viable particles and the MW dose $3 \times 10^{7}$ viable organisms. For other details see Tables 1 and 3.

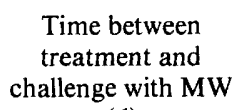

(d)

No. of mice that died after treatment with:

\begin{tabular}{|c|c|c|c|c|c|}
\hline $\begin{array}{c}\text { Phage } \\
\mathrm{R}\left(\mathrm{K} 12 . \mathrm{K}^{+}\right)\end{array}$ & $\begin{array}{c}\text { E. coli } \\
\mathrm{K} 12 . \mathrm{K} 1^{+} \\
\text {extract }\end{array}$ & $\begin{array}{l}\text { Phage } \\
\text { R(MW) }\end{array}$ & $\begin{array}{l}\text { MW } \\
\text { extract }\end{array}$ & Streptomycin & $\begin{array}{l}\text { Sterile } \\
\text { broth }\end{array}$ \\
\hline 0 & 19 & 0 & 20 & 20 & 20 \\
\hline 1 & 19 & 1 & 19 & 20 & 20 \\
\hline 14 & 20 & 6 & 19 & 20 & 20 \\
\hline 17 & 20 & 3 & 12 & 一 & 20 \\
\hline 19 & 20 & 17 & 17 & - & 20 \\
\hline 19 & 20 & 14 & 17 & - & 20 \\
\hline 20 & 20 & 16 & 15 & - & 20 \\
\hline
\end{tabular}

mice, were found to be resistant; all six were $\mathrm{K} 1^{-}$. The numbers of $\mathrm{R}\left(\mathrm{K} 12 . \mathrm{K} 1^{+}\right)$found in the brains of mice examined $12-72 \mathrm{~h}$ after infection were much higher than in mice given $\mathrm{R}\left(\mathrm{K} 12 . \mathrm{K}^{+}\right)$alone (Table 6). The distribution of $\mathrm{R}\left(\mathrm{K} 12 . \mathrm{K} 1^{+}\right)$in the blood and spleen resembled that in the mice given $\mathrm{R}\left(\mathrm{K} 12 . \mathrm{K}^{+}\right)$only.

Effect of giving phage $R\left(K 12 . K 1^{+}\right)$or $R(M W)$ to mice before they were challenged with $M W$

Fewer mice died in groups given phage $\mathrm{R}\left(\mathrm{K} 12 . \mathrm{K} 1^{+}\right) 1,2$ or $3 \mathrm{~d}$ before they were challenged intramuscularly with MW than occurred in similarly challenged groups given an ultrasonicate of $E$. coli $\mathrm{K} 12 . \mathrm{K}^{+}$or sterile broth at these times (Table 11). When phage $\mathrm{R}(\mathrm{MW})$ (i.e. phage $\mathrm{R}$ propagated on $\mathrm{MW}$ ) was used instead of $\mathrm{R}\left(\mathrm{K} 12 . \mathrm{K} 1^{+}\right)$, the protective effect was apparent in mice given phage $5 \mathrm{~d}$ before infection as well as in mice given phage 1 , 2 or $3 \mathrm{~d}$ before infection. The MW extract given $5 \mathrm{~d}$ before challenge, however, also provided some protection. Seven of the mice in the group given this treatment died within $2 \mathrm{~d}$ of infection, the number increasing to 11 by the third day and reaching the final mortality of 12 on the seventh day; all the mice in the corresponding groups given $\mathrm{K} 12 . \mathrm{K}^{+}$extract or sterile broth had died within $2 \mathrm{~d}$ of challenge. Prolonged survival time was also noted in the groups given MW extract 7, 10 or $14 \mathrm{~d}$ before infection with MW. The course of the disease in the groups given streptomycin did not differ from that of the corresponding untreated control groups.

When 20 mice that had been inoculated with $3 \times 10^{8}$ viable particles of $\mathrm{R}\left(\mathrm{K} 12 . \mathrm{K}^{+}\right) 21 \mathrm{~d}$ previously were given a similar dose of this phage into the same gastrocnemius muscle and 3 $\times 10^{7}$ viable organisms of $\mathrm{MW}$ into the opposite muscle, 15 of them died. When 20 mice were treated identically, except that they were not given the first dose of $\mathrm{R}\left(\mathrm{K} 12 . \mathrm{K} 1^{+}\right)$, none showed any signs of ill-health. All of 20 mice that had only been given MW died.

\section{DISCUSSION}

The initial aim of this work was to see whether evidence could be produced, by studying the dynamics of phage/bacterium relationships in vivo, to support the commonly held view that the lack of success that has been obtained in using phages to treat bacterial infections is due mainly to reduced phage activity in vivo and to the rapid emergence of phage-resistant bacteria. Phage $\mathrm{O}$ was only slightly effective in treating infection with $E$. coli $\mathrm{MW}$ because of its low antibacterial activity, noted both in vivo and in vitro. Phage $\mathrm{R}$ was in a completely different category. It was highly active in vitro, fewer than 10 viable organisms being 
sufficient to lyse $10 \mathrm{ml}$ of a broth culture of $\mathrm{MW}$, and this was reflected to a surprisingly high degree in vivo $-3 \times 10^{4}$ phage particles given intramuscularly or $3 \times 10^{3}$ given intravenously were sufficient to cure mice given a potentially lethal intramuscular dose of MW. Although phage R-resistant mutants are fairly common in cultures, they were found in only a few phage-treated mice, where they were confined to the inoculation site and outnumbered by phage-sensitive organisms. Presumably, they did not complicate therapy because they were $\mathrm{K} 1^{-}$: previous studies (Smith \& Huggins, 1980) had revealed that $\mathrm{K} 1^{-}$mutants of $\mathrm{MW}$ are almost completely avirulent for mice. Our findings with phage $\mathrm{R}$, therefore, provide no support for the view that the failure of phage therapy is due to reduced phage activity in vivo and to the rapid emergence of phage-resistant bacteria. Indeed, therapeutic success was due to high in vivo activity and to failure of phage-resistant mutants to proliferate during treatment.

One dose of phage $\mathbf{R}$ was at least equivalent to multiple doses of streptomycin, and more effective than multiple doses of tetracycline, ampicillin, chloramphenicol, or trimethoprim plus sulphafurazole in treating mice infected intramuscularly or intracerebrally with MW. The marked superiority of phage $\mathrm{R}$ over one dose of streptomycin emphasized its self-perpetuating nature in the presence of susceptible bacteria, a most desirable characteristic for any antibacterial agent. Although these facts need not be taken to imply that phage may still have a role to play in the therapy of bacterial infections, they do suggest that certain aspects of the subject may be worthy of further investigation. The following observations indicate that the curative effect of $\mathrm{R}$ was probably due almost entirely to its ability to rapidly destroy MW organisms in the tissues they were infecting: $(a)$ the administration of extracts of E. coli $\mathrm{K} 12 . \mathrm{K}^{+}$, the propagating strain of phage $\mathrm{R}\left(\mathrm{K} 12 . \mathrm{K} 1^{+}\right)$, did not influence the course of the disease produced by intramuscular or intracerebral inoculation of $\mathrm{MW}$; and $(b)$ there was a rapid decrease in the numbers of $\mathrm{MW}$ organisms and a coincidental increase in the numbers of phage particles in the tissues of phage $\mathrm{R}\left(\mathrm{K} 12 . \mathrm{K} 1^{+}\right)$-treated mice, which was more marked than in the tissues of phage $\mathrm{O}$-treated mice.

The decision to employ preparations of phage $R\left(K 12 . K 1^{+}\right)$instead of phage $R(M W)$ in most experiments was made because they would contain less material of bacterial origin in common with MW than would R(MW). Such material might have influenced the course of the disease produced by MW. The highly beneficial effect observed when a preparation of R(MW) was given to mice $5 \mathrm{~d}$ before they were infected with $\mathrm{MW}$ was probably due to the MW material it contained, because this effect was not seen when phage $\mathrm{R}\left(\mathrm{K} 12 . \mathrm{K}^{+}\right)$was given instead of $\mathrm{R}(\mathrm{MW})$, and because the extract of $\mathrm{MW}$, but not of $\mathrm{K} 12 . \mathrm{K}^{+}$, had a beneficial but less marked effect on the course of the disease. This suggests that if phages like $\mathrm{R}$ were ever found to be of value in controlling natural outbreaks of disease, it would be advantageous to use pathogenic bacteria for propagating them, provided the resulting preparations were not toxic, rather than to use a non-pathogen like the $E$. coli $\mathrm{K} 12 . \mathrm{K} 1^{+}$that was used in the present study. It is apparent, though, from the experiment in which $\mathrm{R}\left(\mathrm{K} 12 . \mathrm{K}^{+}\right)$failed to cure $\mathrm{MW}$-infected mice that had been inoculated with this phage $21 \mathrm{~d}$ previously, presumably because the inoculum stimulated phage antibody, that phage antibody could be a complicating factor in phage therapy.

We are grateful to Mr David Moon, Miss Theresa Winstanley and Mr Derek Clarke for their capable technical help. Our thanks are also due to Dr P. M. Biggs, Miss Margaret Lovell, Miss Debra Pulley, Dr B. Rowe and $\mathrm{Mr} \mathrm{P}$. Townsend for assistance in a variety of ways.

\section{REFERENCES}

Gross, R. J., Cheasty, T \& Rowe, B. (1977). Isolation of bacterial phages specific for the K1 polysaccharide antigen of Escherichia coli. Journal of Clinical Microbiology 6, 548-550.
Miles, A. A. \& Misra, S. S. (1938). The estimation of the bactericidal power of blood. Journal of Hygiene 28, 732-749.

Smith. H. Williams (1976). Mutants of Klebsiella 
pneumoniae resistant to several antibiotics. Nature, London 259, 307-308.

Smith, H. Williams \& Huggins, M. B. (1980). The association of the $\mathrm{O} 18, \mathrm{~K} 1$ and $\mathrm{H} 7$ antigens and the Colv plasmid of a strain of Escherichia coli with its virulence and immunogenicity. Journal of General Microbiology 121, 387-400.

Wilson, G. S. \& Miles, A. (1975). Topley and Wilson's Principles of Bacteriology and Immunity, 6th edn, pp. 1634-1636. London: Edward Arnold. 